\title{
CFD simulation for evaluation of optimum heat transfer rate in a heat exchanger of an internal combustion engine
}

\author{
Rajesh Kocheril $^{*}$ and Jacob Elias \\ Department of Mechanical Engineering, Cochin University of Science \& Technology, Kochi, India
}

Received: 25 June 2019 / Accepted: 2 December 2019

\begin{abstract}
Heat exchanger is an essential component of an engine cooling system. Radiators are compact heat exchangers used to transfer the heat absorbed from engine to the cooling media. The jacket cooling water gets cooled and re-circulated into system after exchanging the heat with cooling water in a heat exchanger. Conventional fluids like water, oil, ethylene glycol, etc. possess less heat transfer performance; therefore, it is essential to have a compact and effective heat transfer system to obtain the required heat transfer. A reduction in energy consumption is possible by improving the performance of heat exchanging systems and incorporating various heat transfer enhancement techniques. In this paper, the heat transfer rate using nano-sized ferrofluid with and without magnetization is analysed using CFD simulation and compared with the experimental values obtained from a heat exchanger using water as base fluid. The heat transfer rate is measured using different combinations by varying the percentage of nano particles and by introduction of different magnetic intensity (gauss) on to the ferrofluid. The optimum heat transfer rate and efficiency of heat exchanger is calculated with the different combinations and the values are compared with the values of CFD simulation. CFD simulation was undertaken for water alone as cooling media and for water with ferro particle addition from $2 \%$ to $5 \%$. The difference in temperature observed to be similar with experimental values. The deviation is within the acceptable limit and therefore the experimental findings are validated. The experiment was conducted on a parallel flow heat exchanger with water alone as cooling media, water with varying percentage of ferro fluid and water with varying magnetic intensity on ferrofluid. Percentage of ferro particles added up to where the optimum temperature difference could be obtained and the magnetic intensity also varied up to the optimum value.
\end{abstract}

Keywords: CFD / Simulation heat transfer / Ferro particles

\section{Introduction}

By introduction of magnetic field into the ferrofluid, they transform into pseudo solids, which takes away more heat than liquids. The spike formed by magnetizing the ferrofluid increases the surface area and carries more heat. The temperature difference across the heat exchanger was increased by $11^{\circ} \mathrm{C}$ when $4 \%$ ferro particles were added to the cooling water. When the ferro particles were magnetized, the temperature difference increased to $15^{\circ} \mathrm{C}$. The optimum was at $4 \%$ addition of ferro particles with a magnetic intensity of 300 gauss [3]. Ferrofluids posse more heat carrying capacity than conventional fluids used in heat exchangers. Heat carrying property of ferrofluid increases by magnetization up to a particular magnetic intensity. Beyond that bifurcation takes place and obstruction in flow is observed [5]. Nanofluid refers to fluids by suspending nano particles in the base fluid $[1,2,4]$.

\footnotetext{
* e-mail: rajesh.kocheril@gmail.com
}

Heat carrying capacity of liquid is less compared to solids. Ferrofluids have superior properties which includes variable viscosity, improved thermal conductivity and formation of spike like structure in the presence of an external magnetic field $[6,8]$. Addition of ferro particles or nano particles into cooling water of IC Engines increases the heat transfer which results in the size reduction of heat exchanger [9]. This will facilitate reduction of size of overall weight of the engine, which will reduce the fuel consumption. The world is facing scarcity of drinking water, marine engines and huge diesel power plants use huge quantity of water for cooling the jackets. By using nano-sized ferro particles along with cooling water, the quantity of water carried for cooling the jackets can be reduced thereby increasing the heat transfer, reducing the fuel consumption and usage of fresh water.

Computational Fluid Dynamics (CFD) is the art of replacing the PDEs used in Fluid flow and heat transfer systems, by a set of algebraic equations which can be solved using digital computers. Computational fluid dynamics (CFD) is the science of predicting fluid flow, heat transfer, 
mass transfer, chemical reactions, and related phenomena by solving the mathematical equations which govern these processes using a numerical process. The heat transfer rate using nano-sized ferrofluid with and without magnetization is analysed using CFD simulation and compared with the experimental values obtained from a heat exchanger using water as base fluid. The heat transfer rate is measured using different combinations by varying the percentage of nano particles and by introduction of different magnetic intensity (gauss) on to the ferrofluid. The optimum heat transfer rate and efficiency of heat exchanger is calculated with the different combinations and the values are compared with the values of CFD simulation. CFD simulation consisted of pre processing stage, processing stage and post processing stage. Pre processing stage consists of preparing the geometry, meshing the geometry, specifying boundaries and continuum types. Processing stage follows setting the numerical method, specifying the boundary conditions, initialization and solving and post processing stage analyses the results.

\section{Procedure for setting up the CFD numerical model}

Select appropriate physical models.

Turbulence, combustion, multiphase, etc.

Define material properties.

- Fluid.

- Solid.

- Mixture.

Prescribe operating conditions.

Prescribe boundary conditions at all boundary zones.

Provide an initial solution.

Set up solver controls.

Set up convergence monitors.

\subsection{Discretization}

Domain is discretized into a finite set of control volumes or cells. The discredited domain is called the "grid" or the "mesh."

\subsection{Computing the solution}

- The discretized conservation equations are solved iteratively. A number of iterations are usually required to reach a converged solution.

Convergence is reached when:

- changes in solution variables from one iteration to the next are negligible,

- residuals provide a mechanism to help monitor this trend,

- overall property conservation is achieved.

The accuracy of a converged solution is dependent upon:

- appropriateness and accuracy of the physical models,

- grid resolution and independence,

- problem setup.

\section{CFD analysis}

Simulation consists of the following steps:

\section{Pre- processing}

- Preparing the geometry

- Meshing the geometry

- Specifying boundaries and continuum types

\section{Processing}

- Setting the numerical method

- Specifying the boundary conditions

- Initialization

- Solving

\section{Post processing}

- Analyzing the results

\subsection{Computational domain}

Below shown are both front and side views of the computational domain used for the CFD analysis. Here all dimensions are in $\mathrm{cm}$.

\subsubsection{Pre processing}

\subsubsection{Preparing the geometry}

The geometry of the Radiator is generated in Ansys Design Modeler. Figure 1 shows the front view of geometry created and Figure 2 shows isometric zoomed view of geometry created. $<\mathrm{H} 4>$ Meshing the geometryTetrahedral mesh was selected for meshing the domain, because it produces quick mesh and easily solves this mesh type [7]. The mesh details are:

Mesh Interval size $=4 \times 10^{-4} \mathrm{~m}$

No of nodes $=1188746$

Type of cells $=$ Tetrahedral

Figure 3 shows the meshed model and Figure 4 shows the zoomed isometric meshed model.

\subsubsection{Boundary condition and continuum types}

The boundary name and type provided to the radiator is shown in Table 1.

\subsubsection{Processing}

It is the next stage of numerical simulation. After completing the geometry in Design Modeler and meshing the file is open in ANSYS fluent. Fluent is the software used for processing purpose. For solving, suitable boundary conditions are provided.

\section{Governing equations}

- Continuity equation

- Momentum equation (Navier-Stokes equation)

- Energy equation

\subsection{Numerical model}

- Algorithm - SIMPLE (Semi Implicit Method for Pressure Linked Equations) 


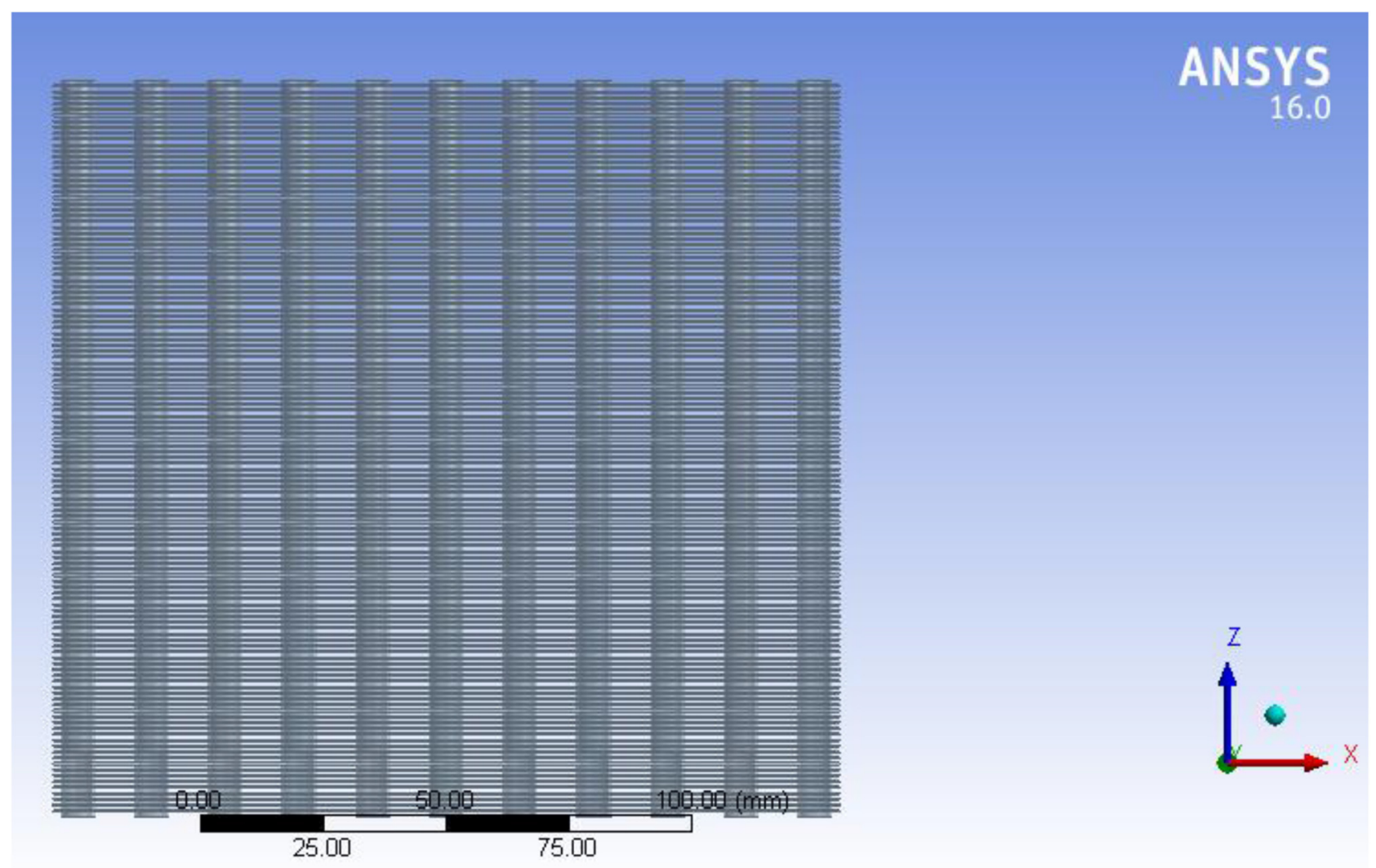

Fig. 1. Front view of geometry created.

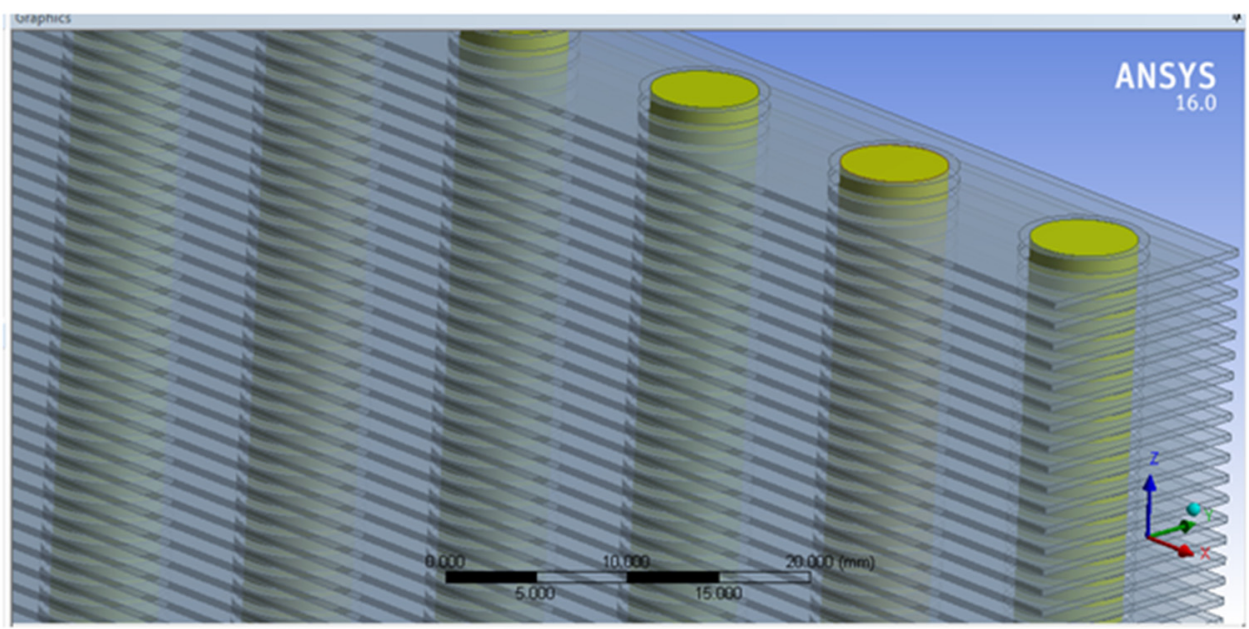

Fig. 2. Isometric zoomed view of geometry created.

- Flow type - Steady, Viscous Laminar

- Momentum - 2nd order upwind

- Energy - 2nd order upwind

\subsection{Boundary conditions used}

Mass flow rate $=35 \mathrm{lit} / \mathrm{min}$

Hot water inlet

- Velocity $=0.015 \mathrm{~m} / \mathrm{s}$

- Reynolds number $=106$ (so Laminar is selected)
- Temperature $=333 \mathrm{~K}, 343 \mathrm{~K}$ and $353 \mathrm{~K}$ (for different cases)

Hot water outlet

$-P_{\text {out }}=p_{\text {atm }}=$ Zero (gauge)

$-\mathrm{dT} / \mathrm{ds}=0$.

Fin walls

- No slip

- Heat lost by convection to free stream temperature of 300 $\mathrm{K}$

- Convective heat transfer coefficient, $\mathrm{h}=10 \mathrm{~W} / \mathrm{m}^{2} \mathrm{~K}$ 


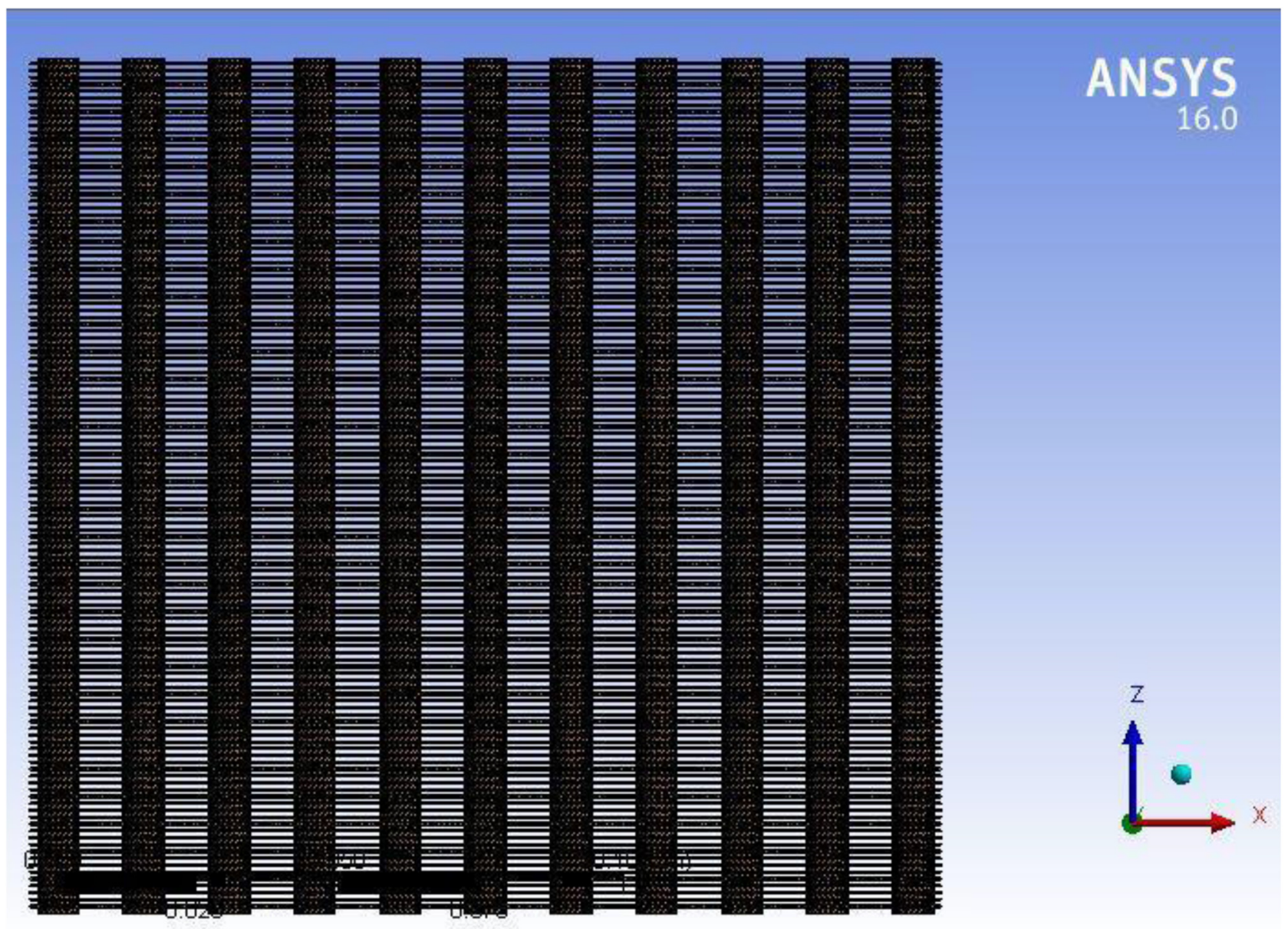

Fig. 3. Meshed model

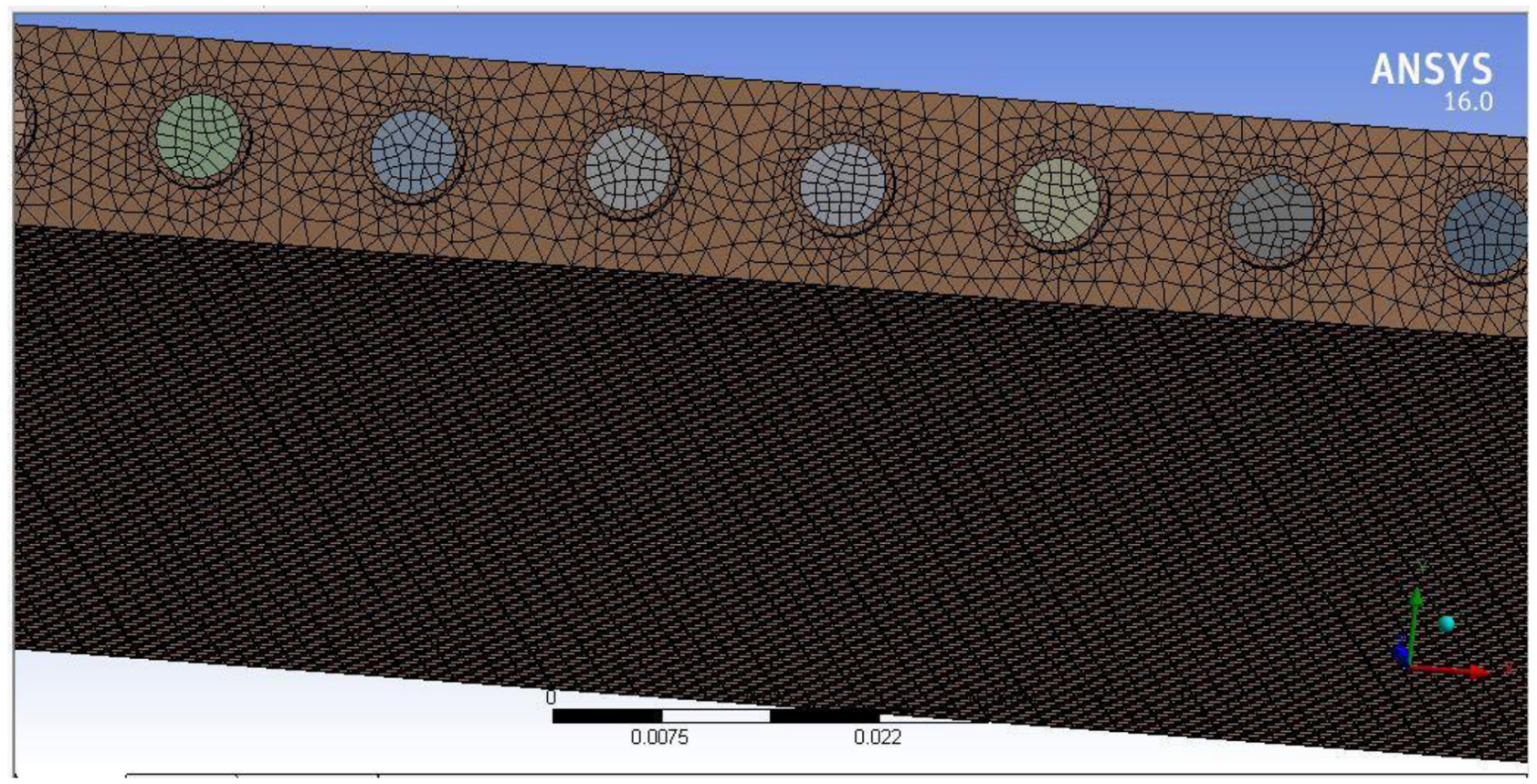

Fig. 4. Zoomed isometric view of meshed model. 
Table 1. Boundary name and type provided to the radiator.

\begin{tabular}{ll}
\hline Boundary name & Type \\
\hline HOT INLET (for fluid entry through vertical pipes) & VELOCITY INLET \\
HOT OUTLET(for fluid exit through vertical pipes) & PRESSURE OUTLET \\
Fin walls & Walls \\
TUBE VOLOUME & FLUID (Water or ferrofluid) \\
FIN VOLUME & SOLID (Aluminium) \\
\hline
\end{tabular}

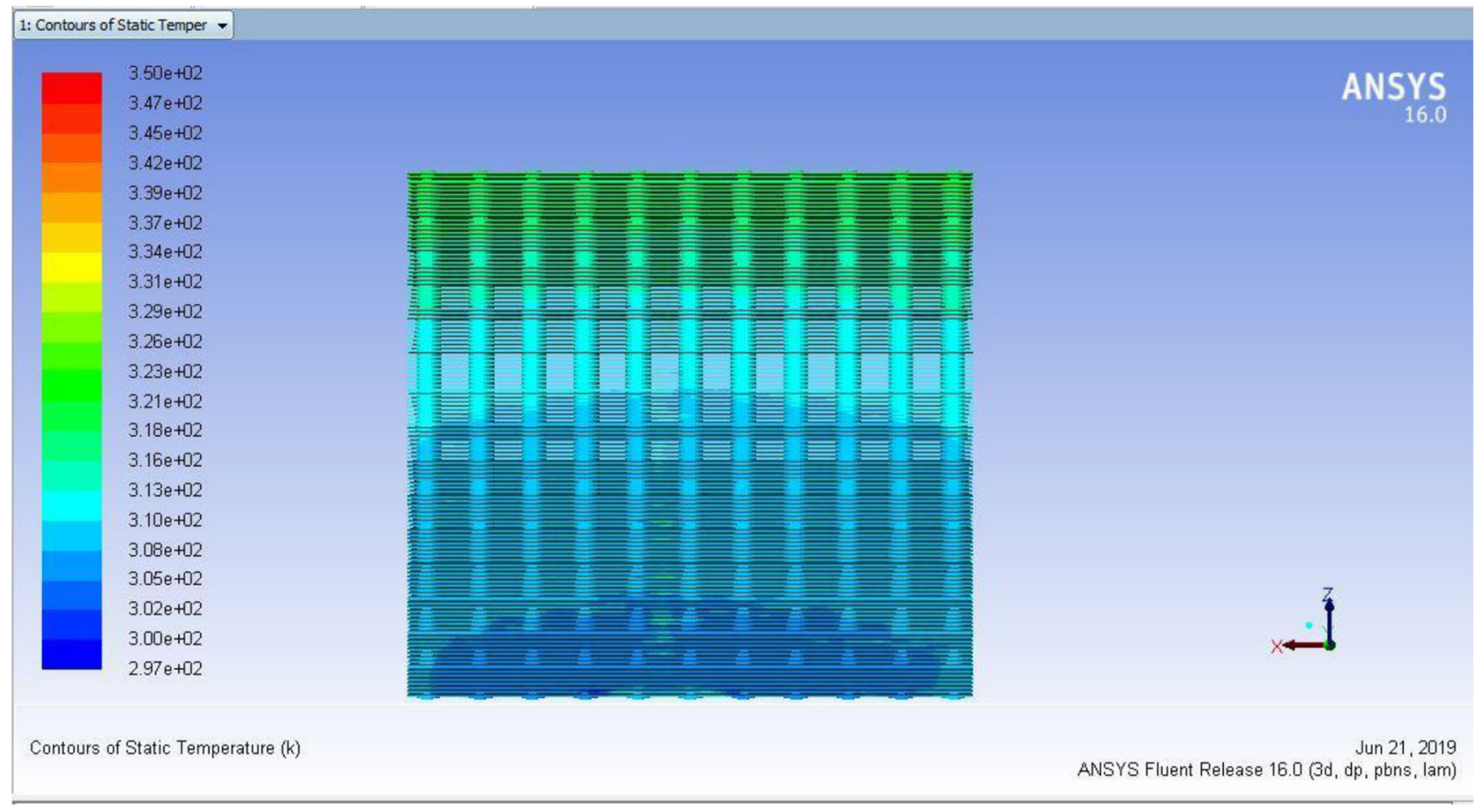

Fig. 5. Temperature contour on the surface of fin.

Table 2. Temperature measurement with water as cooling medium.

\begin{tabular}{llllll}
\hline$T_{\mathrm{ci}}$ & $T_{\text {co }}$ & $T_{\mathrm{hi}}$ & $T_{\mathrm{ho}}$ & $\Delta T$ & $\varepsilon$ \\
\hline 34.87 & 40.63 & 60 & 52.74 & 7.26 & 0.288 \\
35.38 & 41.67 & 70 & 62.21 & 6.29 & 0.255 \\
36.78 & 41.78 & 80 & 73.50 & 5.00 & 0.150 \\
\hline
\end{tabular}

Table 3. Temperature measurement with water as cooling medium comparison with CFD.

\begin{tabular}{lllll}
\hline Sr.No & Fluid inlet temperature $(\mathrm{K})$ & Fluid Outlet temperature $(\mathrm{K})$ & \multicolumn{2}{l}{ \% Deviation } \\
\hline & & Experiment & CFD & \\
1 & $333\left(60^{\circ} \mathrm{C}\right)$ & 325.74 & 320.41 & 1.63 \\
2 & $343\left(70^{\circ} \mathrm{C}\right)$ & 335.21 & 330.79 & 1.32 \\
3 & $353\left(80^{\circ} \mathrm{C}\right)$ & 346.5 & 342.89 & 1.04 \\
\hline
\end{tabular}


Table 4. Temperature measurement with addition of ferro particles (experimental results).

\begin{tabular}{lllllll}
\hline \% of ferro fluid & $T_{\mathrm{ci}}$ & $T_{\mathrm{co}}$ & $T_{\mathrm{hi}}$ & $T_{\mathrm{ho}}$ & $\Delta \mathrm{T}$ & $\varepsilon$ \\
\hline 2 & $34{ }^{\circ} \mathrm{C}$ & $42{ }^{\circ} \mathrm{C}$ & $60{ }^{\circ} \mathrm{C}$ & $50.5{ }^{\circ} \mathrm{C}$ & $8.0{ }^{\circ} \mathrm{C}$ & 0.36 \\
2 & $36{ }^{\circ} \mathrm{C}$ & $44{ }^{\circ} \mathrm{C}$ & $70{ }^{\circ} \mathrm{C}$ & $60.5{ }^{\circ} \mathrm{C}$ & $8.0{ }^{\circ} \mathrm{C}$ & 0.279 \\
2 & $36{ }^{\circ} \mathrm{C}$ & $44.5{ }^{\circ} \mathrm{C}$ & $80{ }^{\circ} \mathrm{C}$ & $70.5{ }^{\circ} \mathrm{C}$ & $8.5{ }^{\circ} \mathrm{C}$ & 0.215 \\
2 & $35{ }^{\circ} \mathrm{C}$ & $42{ }^{\circ} \mathrm{C}$ & $60{ }^{\circ} \mathrm{C}$ & $51.5{ }^{\circ} \mathrm{C}$ & $7.0{ }^{\circ} \mathrm{C}$ & 0.34 \\
2.5 & $34{ }^{\circ} \mathrm{C}$ & $43{ }^{\circ} \mathrm{C}$ & $70{ }^{\circ} \mathrm{C}$ & $59.5{ }^{\circ} \mathrm{C}$ & $9.0{ }^{\circ} \mathrm{C}$ & 0.291 \\
2.5 & $35{ }^{\circ} \mathrm{C}$ & $43{ }^{\circ} \mathrm{C}$ & $80{ }^{\circ} \mathrm{C}$ & $70.5{ }^{\circ} \mathrm{C}$ & $8.0{ }^{\circ} \mathrm{C}$ & 0.257 \\
2.5 & $31{ }^{\circ} \mathrm{C}$ & $41{ }^{\circ} \mathrm{C}$ & $60{ }^{\circ} \mathrm{C}$ & $48.5{ }^{\circ} \mathrm{C}$ & $10.0{ }^{\circ} \mathrm{C}$ & 0.396 \\
3 & $34.5{ }^{\circ} \mathrm{C}$ & $44.7{ }^{\circ} \mathrm{C}$ & $70{ }^{\circ} \mathrm{C}$ & $58.5{ }^{\circ} \mathrm{C}$ & $10.2{ }^{\circ} \mathrm{C}$ & 0.323 \\
3 & $36{ }^{\circ} \mathrm{C}$ & $47{ }^{\circ} \mathrm{C}$ & $80{ }^{\circ} \mathrm{C}$ & $67.5{ }^{\circ} \mathrm{C}$ & $11.0{ }^{\circ} \mathrm{C}$ & 0.28 \\
3 & $34{ }^{\circ} \mathrm{C}$ & $45{ }^{\circ} \mathrm{C}$ & $60{ }^{\circ} \mathrm{C}$ & $47.5{ }^{\circ} \mathrm{C}$ & $11.0{ }^{\circ} \mathrm{C}$ & 0.481 \\
4 & $34.36{ }^{\circ} \mathrm{C}$ & $45.31{ }^{\circ} \mathrm{C}$ & $70{ }^{\circ} \mathrm{C}$ & $57.5{ }^{\circ} \mathrm{C}$ & $10.95{ }^{\circ} \mathrm{C}$ & 0.350 \\
4 & $34.38{ }^{\circ} \mathrm{C}$ & $45.38{ }^{\circ} \mathrm{C}$ & $80{ }^{\circ} \mathrm{C}$ & $67.5{ }^{\circ} \mathrm{C}$ & $11.0{ }^{\circ} \mathrm{C}$ & 0.274 \\
4 & $34{ }^{\circ} \mathrm{C}$ & $45.3{ }^{\circ} \mathrm{C}$ & $60{ }^{\circ} \mathrm{C}$ & $47.2{ }^{\circ} \mathrm{C}$ & $11.3{ }^{\circ} \mathrm{C}$ & 0.492 \\
5 & $33{ }^{\circ} \mathrm{C}$ & $49.5{ }^{\circ} \mathrm{C}$ & $70{ }^{\circ} \mathrm{C}$ & $57.4{ }^{\circ} \mathrm{C}$ & $10.5{ }^{\circ} \mathrm{C}$ & 0.34 \\
5 & $41.06{ }^{\circ} \mathrm{C}$ & $51.31{ }^{\circ} \mathrm{C}$ & $80{ }^{\circ} \mathrm{C}$ & $63.2{ }^{\circ} \mathrm{C}$ & $10.25{ }^{\circ} \mathrm{C}$ & 0.431 \\
5 & & &
\end{tabular}

Table 5. Temperature measurement with addition of $2 \%$ ferro particles (comparison with CFD).

\begin{tabular}{lllll}
\hline S.No & Fluid inlet temperature $(\mathrm{K})$ & Fluid outlet temperature $(\mathrm{K})$ & \% Deviation & \\
\hline & & Experiment & $\mathrm{CFD}$ & \\
1 & $333\left(60^{\circ} \mathrm{C}\right)$ & 323.5 & $318.47 \mathrm{~K}$ & 1.55 \\
2 & $343\left(70^{\circ} \mathrm{C}\right)$ & 333.5 & 332.34 & 0.347 \\
3 & $353\left(80^{\circ} \mathrm{C}\right)$ & 343.5 & 339.87 & 1.06 \\
\hline
\end{tabular}

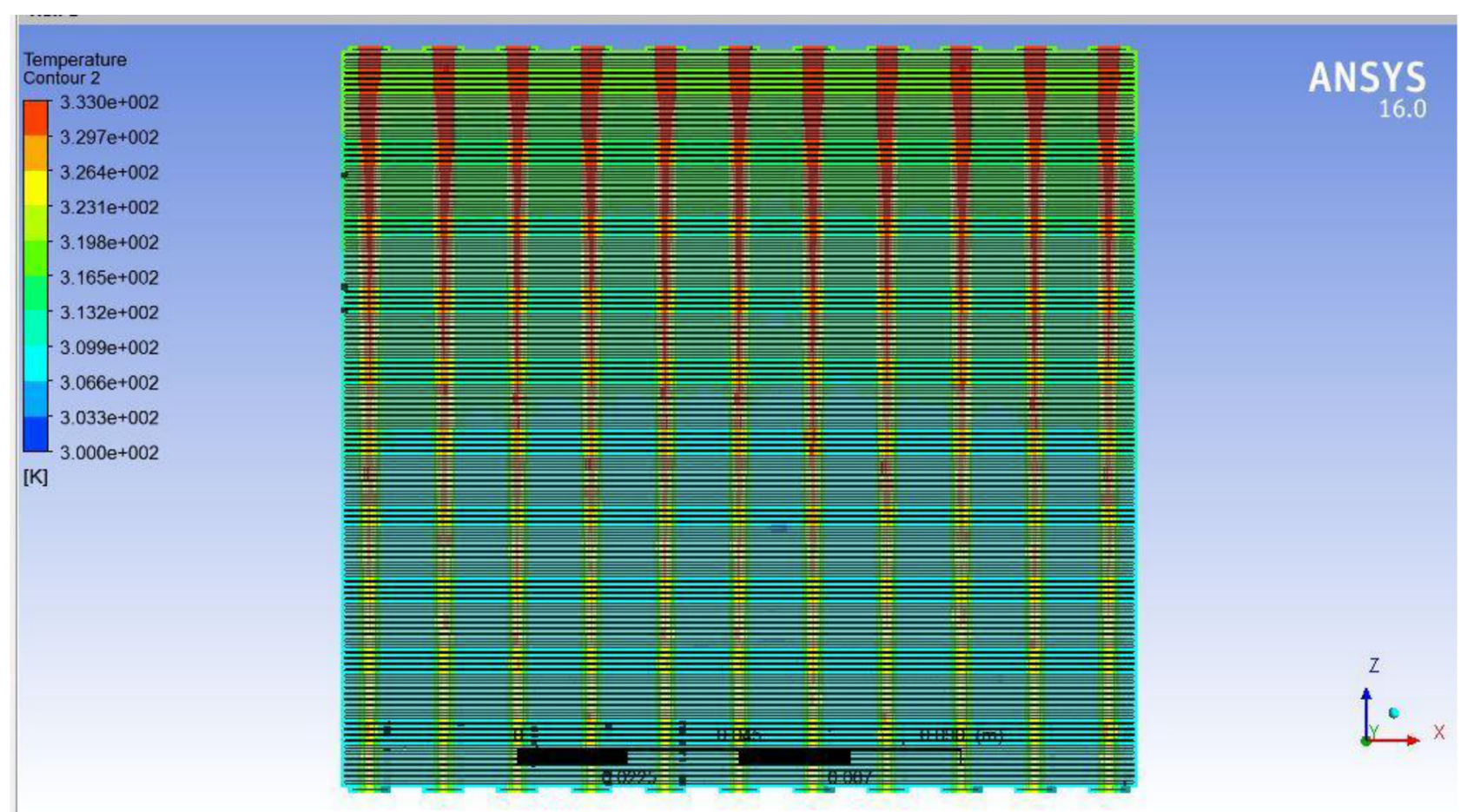

Fig. 6. Temperature contour (planar sectional view). 


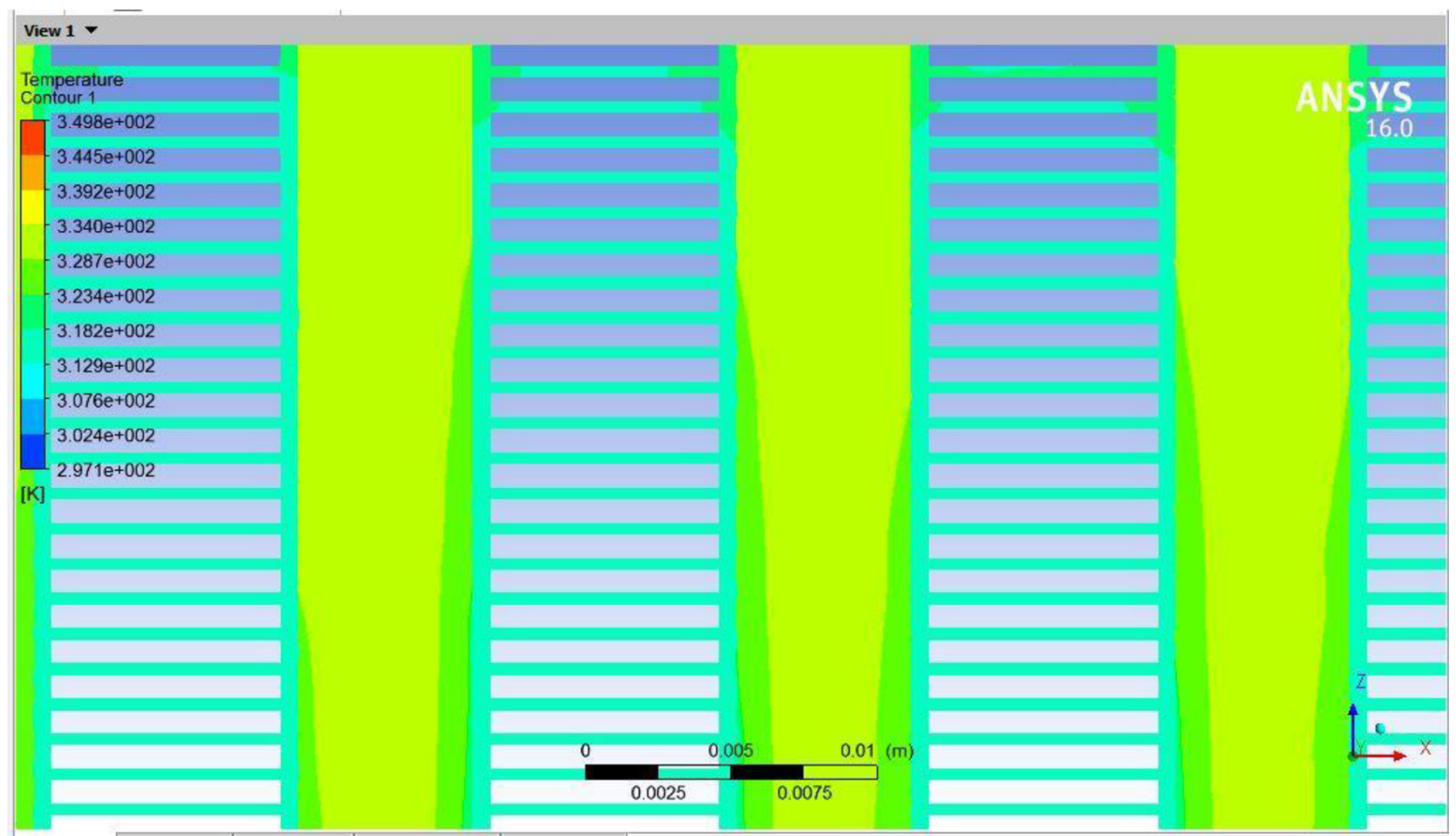

Fig. 7. Temperature contour (planar sectional view (zoomed view)).

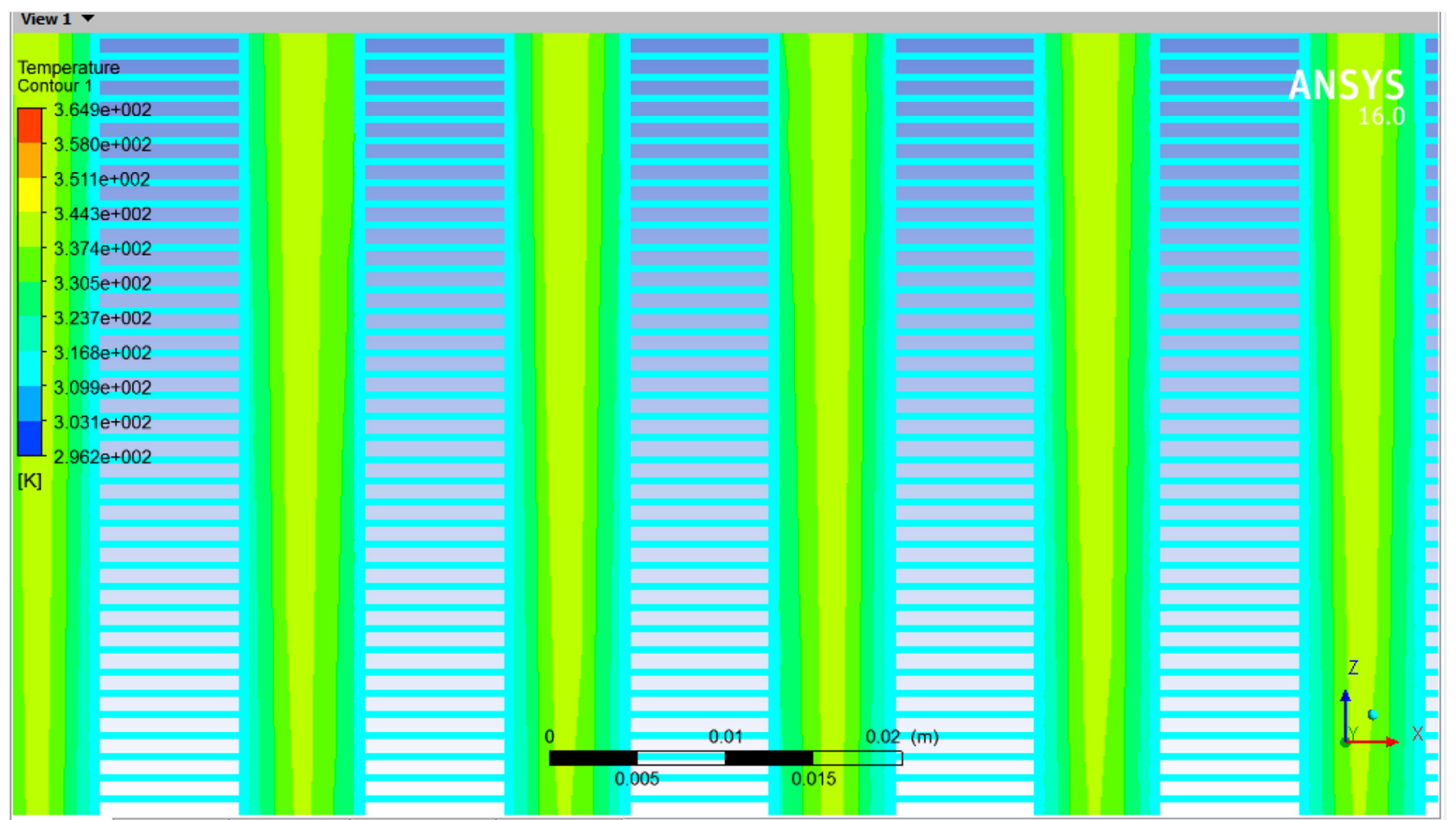

Fig. 8. Temperature contour (planar sectional view (zoomed view)). 


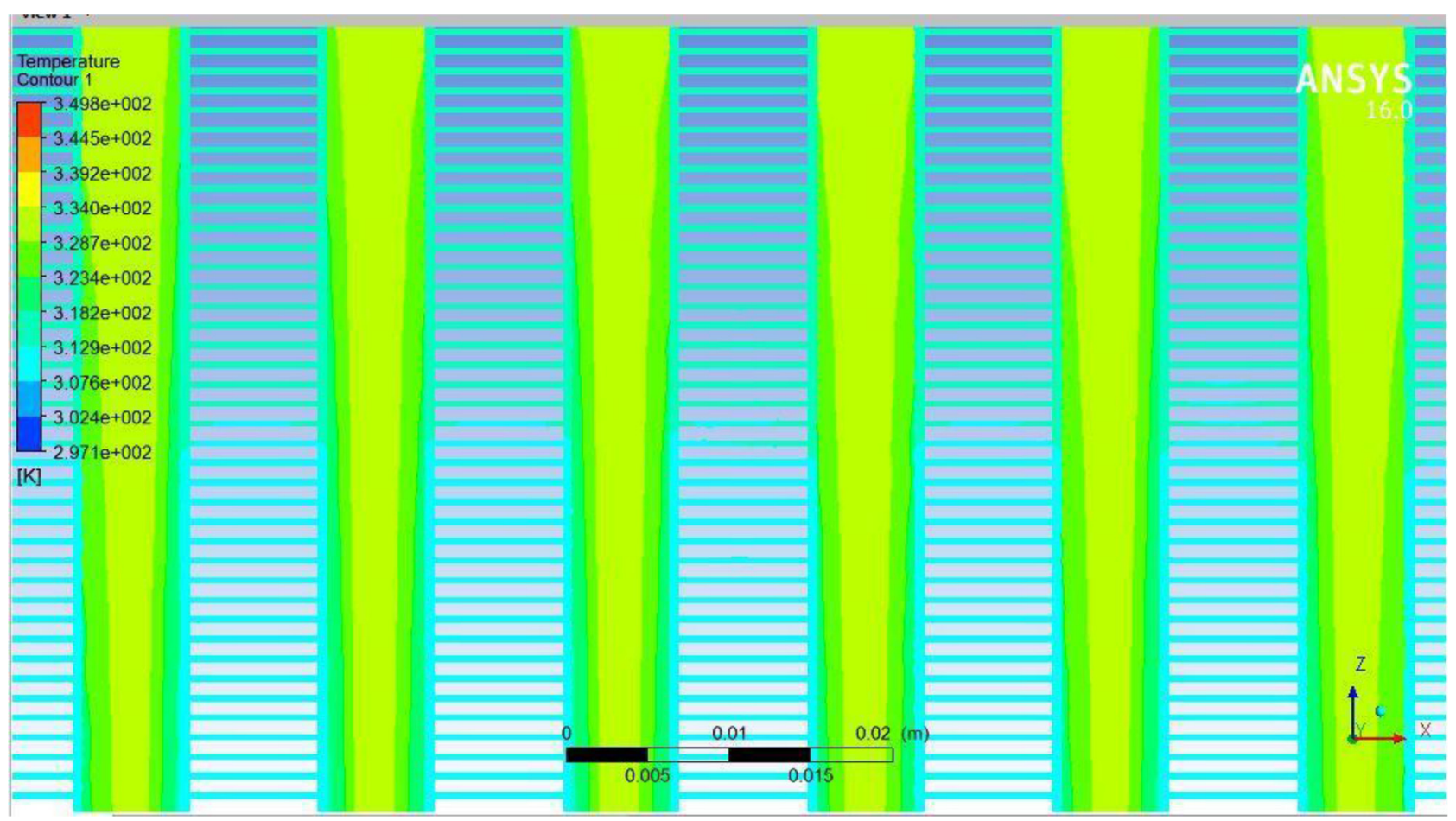

Fig. 9. Temperature contours for water with $2 \%$ ferro particle (hot water inlet temperature $333 \mathrm{~K}\left(60{ }^{\circ} \mathrm{C}\right)$.

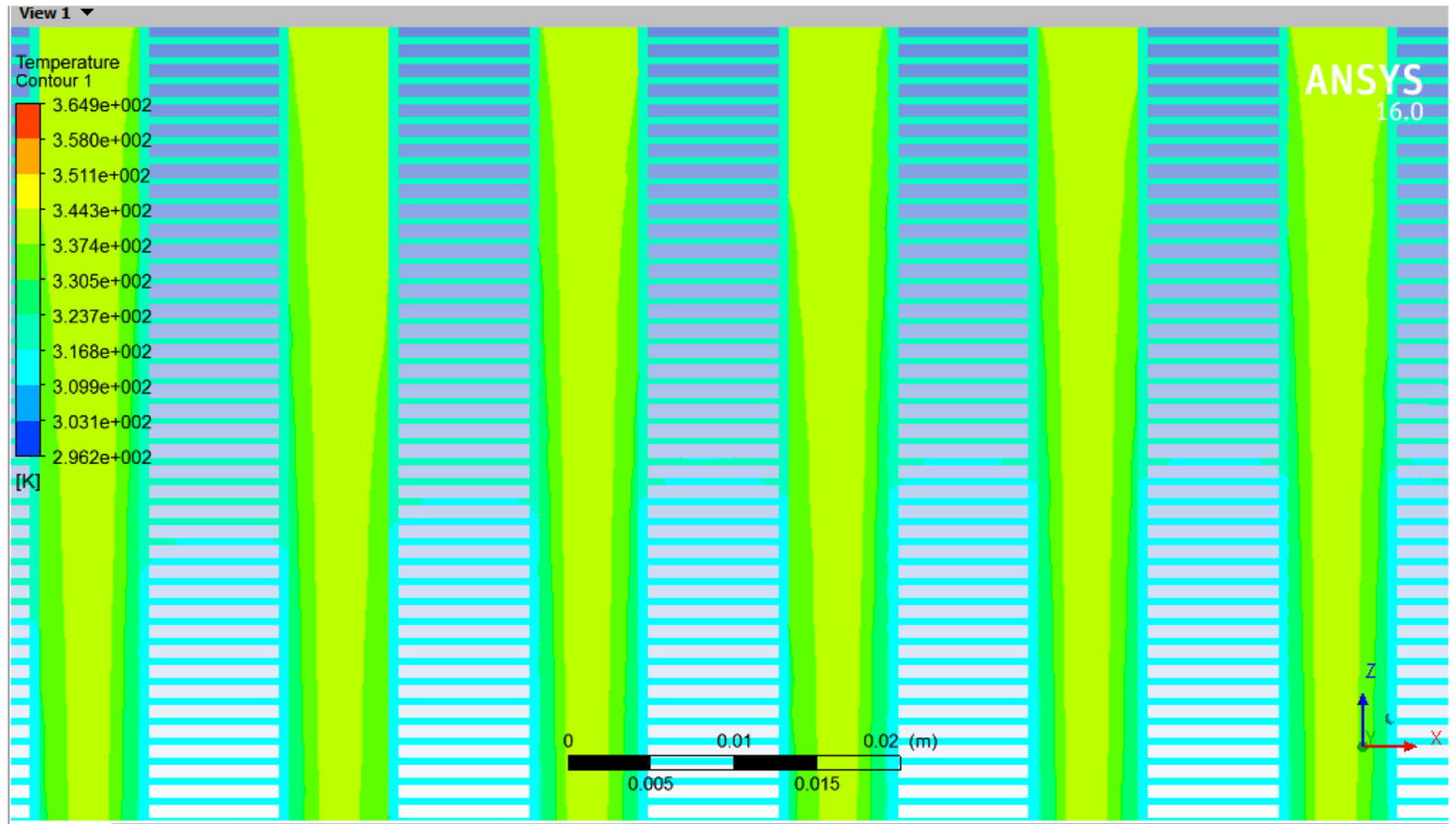

Fig. 10. Temperature contours for water with $2 \%$ ferro particle (hot water inlet temperature $343 \mathrm{~K}\left(70^{\circ} \mathrm{C}\right)$. 


\section{Results and discussion}

From CFD analysis, at hot water inlet temperature $333 \mathrm{~K}$ $\left(60^{\circ} \mathrm{C}\right)$ the resultant hot water outlet temperature is $320.41 \mathrm{~K}$ (using area weighted average at the fluid outlet). Figure 5 shows temperature contour on the surface of fin, Figure 6 shows temperature contour (planar sectional view) and Figure 7 shows temperature contour (planar sectional view (zoomed view)).

Figure 8 shows the temperature contour (planar sectional view (zoomed view)) with hot water inlet temperature $343 \mathrm{~K}\left(70^{\circ} \mathrm{C}\right)$ resulted in hot water outlet temperature $330.79 \mathrm{~K}$ (using area weighted average at the fluid outlet) using CFD.

Temperature contour with $2 \%$ ferro particle addition at hot water inlet temperature $333 \mathrm{~K}\left(60^{\circ} \mathrm{C}\right)$ shows hot water outlet temperature $318.47 \mathrm{~K}$ (using area weighted average at the fluid outlet) using CFD simulation shown in Figure 9. The total heat transfer rate is $479.67 \mathrm{~W}$ as per CFD analysis.

Temperature contour with $2 \%$ ferro particle addition at hot water inlet temperature $343 \mathrm{~K}\left(70^{\circ} \mathrm{C}\right)$ shows hot water outlet temperature $332.34 \mathrm{~K}$ (using area weighted average at the fluid outlet) using CFD simulation is shown in Figure 10. The total heat transfer rate is $499.72 \mathrm{~W}$ as per CFD analysis.

Temperature contour with $2 \%$ ferro particle addition at hot water inlet temperature $353 \mathrm{~K}\left(80^{\circ} \mathrm{C}\right)$ shows hot water outlet temperature $339.87 \mathrm{~K}$ (using area weighted average at the fluid outlet) using CFD simulation is shown in Figure 10. The total heat transfer rate is $515.93 \mathrm{~W}$ as per CFD analysis.

\subsection{Comparison of CFD and experimental results}

- Water alone as cooling fluid (experimental result).

- Water alone as cooling fluid (comparison with CFD simulation).

- Water with addition of ferro particles (experimental result).

- Water with $2 \%$ of ferrofluid (compression with CFD simulation).

\section{Conclusion}

Heat transfer rate using nano-sized ferrofluid with and without magnetization is analysed using CFD simulation and compared with the experimental values obtained from a heat exchanger using water as base fluid. The heat transfer rate is measured using different combinations by varying the percentage of nano particles and by introduction of different magnetic intensity (gauss) on to the ferrofluid. The optimum heat transfer rate and efficiency of heat exchanger is calculated with the different combinations and the values are compared with the values of CFD simulation

CFD simulation was undertaken for water alone as cooling media and for water with ferro particle addition from $2 \%$ to $5 \%$. The result of the analysis shows that the values are comparable with experimental values. The temperature difference across the heat exchanger was $6{ }^{\circ} \mathrm{C}$ when water alone was used as cooling media. At $4 \%$ addition of ferro particles into the cooling water the temperature difference across the heat exchanger increased to $11^{\circ} \mathrm{C}$. When the ferro particles were magnetized, the temperature difference $(\Delta T)$ increased to $15^{\circ} \mathrm{C}$. The result of CFD simulation using FLUENT software shows that the values obtained from experiment is similar.

\section{References}

1. S.U.S. Choi, in Enhancing thermal conductivity of fluids with nanoparticles, edited by D.A. Siginer, FED-Vol. 231, 99-105 (1995)

2. E. Abu-Nada, Application of nano fluids for heat transfer enhancement of separated flows encountered in a backward facing step, Int. J. Heat Fluid Flow 29, 242-249 (2008)

3. R. Kocheril, J. Elias, Evaluation of optimum heat transfer rate on heat exchanger of internal combustion engines using magnetized ferro fluid, J. Adv. Res. Dyn. Control Syst. 10, 899-905 (2018)

4. S. Kakac, A. Pramuanjaroenkij, Review of convective heat transfer enhancement with nano fluids, Int. J. Heat Mass Transf. 52, 3187-3196 (2009)

5. R. Kocheril, J. Elias, Effect of magnetized ferro fluids in heat exchanging- a review, Int. J. Innov. Eng. Technol. 10, 41-47 (2018)

6. X.-Q. Wang, A.S. Mujumdar, Heat transfer characteristics of nanofluids: a review, Int. J. Therm. Sci. 46, 1-19 (2007)

7. S. Jayesh, J. Elias, Finite element modeling and random vibration analysis of BGA electronic packagesoldered using lead free solder alloy $\mathrm{Sn}-1 \mathrm{Cu}-1 \mathrm{Ni}-1 \mathrm{Ag}$, Int. J. Simul. Multidisci. Des. Optim. 10, A11 (2019)

8. S. Mojumdar et al., Magnetic field on natural convection and entropy generation in a half-moon shaped cavity with semicircular bottom heater having different ferrofluid inside, J. Magn. Magn. Mater. 407, 412-424 (2016)

9. M. Edalatpour, L. Liu, A.M. Jacobi, K.F. Eid, A.D. Sommers, Managing water on heat transfer surfaces: a critical review of techniques to modify surface wetability for applications with condensation or evaporation, Appl. Energy 222, 967-992 (2018)

Cite this article as: Rajesh Kocheril, Jacob Elias, CFD simulation for evaluation of optimum heat transfer rate in a heat exchanger of an internal combustion engine, Int. J. Simul. Multidisci. Des. Optim. 11, 6 (2020) 